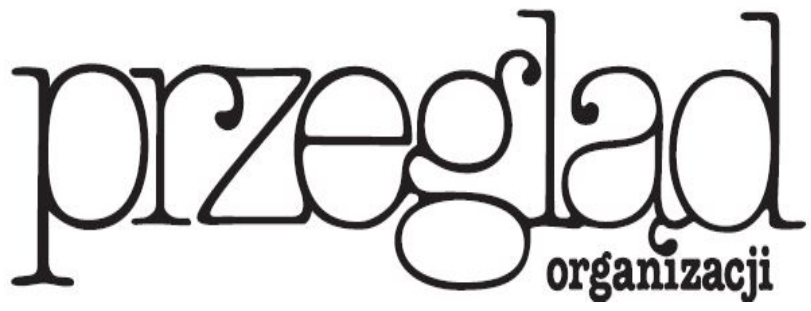

Miesięcznik TNOiK

Założył Karol Adamiecki w 1926 r.

\title{
MODEL ZARZADZANIA PROCESOWEGO Z WYKORZYSTANIEM NOWOCZESNYCH NARZĘDZI PRZEMYSŁU 4.0
}

https://doi.org/10.33141/po.2019.08.01

\section{Leszek Kiełtyka, Kamila Charciarek}

\section{Wprowadzenie}

$\mathbf{R}$ ozwój zaawansowanych technik informatycznych, technologii informacyjnych i komunikacyjnych oraz wirtualizacji modeli biznesowych jest wynikiem zmian dotychczasowych preferencji i oczekiwań klientów (Bembenek, 2017, s. 32). Działania te stanowią o konkurencyjności przedsiębiorstw, dlatego też można zaobserwować dążenie podmiotów gospodarczych do zwiększania zakresu prowadzonych przedsięwzięć inwestycyjnych. Takie działania wymagają od decydentów wprowadzania zmian w przyjętej strategii rozwoju, strukturze organizacyjnej, jak również zastosowania nowoczesnych rozwiązań w procesach produkcyjnych. Celem podjętych działań jest utrzymanie dotychczasowej liczby klientów oraz pozyskanie nowych, a w konsekwencji zwiększenie zysków ze sprzedaży wyrobów lub usług (Kraszewska, Pujer, 2017, s. 16).

Prowadząc analizę literatury przedmiotu, można zapoznać się z licznymi opracowaniami dotyczącymi współczesnych procesowych modeli firm. Modele te różnią się
Przegląd Organizacji, Nr 8 (955), 2019, ss.5-12

www.przegladorganizacji.pl @Towarzystwo Naukowe Organizacji i Kierownictwa (TNOiK)

większą lub mniejszą liczbą szczegółów. Wszystkie jednak bazują na definicji procesu, który zapisany jest w ten sposób, że „Procesem nazywamy zbiór czynności, które przetwarzają produkty o podobnym charakterze i odwołują się do wspólnego obszaru wiedzy”. Tak więc przykładowo model firmy według Deminga opiera się na „walce” o jakość, gdzie wcześniejszy model w epoce Taylorowskiej był „walką" o produktywność. Model Silvestro ukierunkowany jest głównie na system zarządzania jakością (Silvestro, 1998, s. 303-328). P. Zaskórski oraz P. Warszewski (2015, s. 809-825) przedstawili model zarządzania procesowego z wykorzystaniem nowoczesnych narzędzi stosowanych aktualnie w rozwiązaniach bazujących na Przemyśle 4.0, w którym uskuteczniona jest integracja działań procesowych w sferze informacyjno-decyzyjnej i dynamiczne współdziałanie podmiotów zorientowanych na wspólną wartość, kierowaną przez realizatorów rozproszonych procesów decyzyjnych. 
Elementem konkurencyjności przedsiębiorstw jest również racjonalne pozyskiwanie i gromadzenie dostępnych zasobów informacyjnych oraz ich przetwarzanie w użyteczną wiedzę, której wykorzystanie może przyczynić się do skrócenia czasu realizacji poszczególnych operacji i procesów (Sobińska, 2016, s. 93-94). Oznacza to możliwość produkcji wyrobów, dostosowanych do indywidualnych preferencji klientów, a tym samym optymalizację poziomu ryzyka utraty reputacji ${ }^{1}$, które stanowi o wystąpieniu niezadowolenia z użytkowania wyrobów, wyprodukowania wadliwej partii produktów i konieczności pokrycia kosztów naprawy lub ich wycofania ze sprzedaży (Szwajca, 2017, s. 231-232; Szwajca i in., 2014, s. 10-15). Dlatego też istotne znaczenie w rozwoju przedsiębiorstw ma rozbudowa infrastruktury informatycznej i analitycznej, między innymi w wyniku implementacji narzędzi, takich jak: Big Data, chmura obliczeniowa, Internet Rzeczy oraz wysoko zaawansowane systemy informatyczne (Raport Smart Industry Polska, 2018, s. 5-6). Pozyskiwanie, przetwarzanie i transfer danych $\mathrm{w}$ czasie rzeczywistym pozwala na integracje poszczególnych obszarów funkcjonowania przedsiębiorstw oraz dostosowanie oferty do występujących zmian rynkowych z uwzględnieniem predyspozycji i możliwości organizacji (Olender-Skorek, 2017, s. 38; Kiełtyka, 2017a, s. 32).

Celem niniejszego opracowania jest przedstawienie modelu zarządzania procesowego oraz określenie wpływu i znaczenia implementacji narzędzi Przemysłu $4.0^{2} \mathrm{w}$ zarządzaniu procesowym polskich przedsiębiorstw ${ }^{3}$. Wykorzystanie wysoko zaawansowanych technologii w znaczącym stopniu decyduje o rozwoju organizacji, między innymi $\mathrm{w}$ wyniku zwiększenia prawdopodobieństwa dostosowania się do zmian zachodzących w jej otoczeniu. Celem utylitarnym opracowania jest dokonanie oceny wyników badań przedstawionych $\mathrm{w}$ raporcie przedsiębiorstwa PricewaterhouseCoopers ${ }^{4}$ (PwC) „Przemysł 4.0, czyli wyzwania współczesnej produkcji ". W artykule zaprezentowano koncepcyjny model zarządzania procesowego, bazujący na wysoko zaawansowanych narzędziach informatycznych, szeroko pojętej analityce i robotyzacji procesów produkcyjnych. Uważa się, iż zastosowanie opracowanego modelu może w znaczący sposób wpłynąć na poprawę funkcjonowania przedsiębiorstw poprzez zwiększenie transferu wiedzy, skrócenie czasu realizacji poszczególnych procesów, a w konsekwencji produkcję i sprzedaż wyrobów w odniesieniu do aktualnych zapotrzebowań popytowych.

\section{Zastosowanie narzędzi Przemysłu 4.0 w polskich przedsiębiorstwach}

$\mathbf{P}$ rzemysł 4.0 obejmuje głównie zmianę paradygmatu wytwarzania. Nie jest to, jak do niedawna, dążenie do uzyskania efektu minimalizacji kosztów jednostkowych. Realizacja działań polega głównie na tak zwanej personalizacji produkcji. Czynności, jakie są rekomendowane, to przede wszystkim operacje $\mathrm{z}$ wykorzystaniem narzędzi internetowych. Producenci starają się mieć o nas jak najwięcej informacji, wykorzystując między innymi remarketing, relacje za pomocą newsletterów czy też różne formy promocji. Działania te nie są zdominowane przez minimalizację kosztów, lecz wykorzystują szansę związaną z tworzeniem produktu mniej szablonowego, lepiej dostosowanego do oczekiwań i preferencji konsumenta. Zakłada się, że Przemysł 4.0 mocno związany jest $\mathrm{z}$ mentalnością obecnych klientów. $\mathrm{W}$ tym rozumieniu nie ma znaczenia, czy chodzi o klienta indywidualnego, grupę klientów przedsiębiorstwa czy grupę społeczną. Osoby związane z Przemysłem 4.0 wykorzystują myślenie w przestrzeni wirtualnej, a konkretna realizacja działań jest dla nich elementem wtórnym.

Wykorzystanie poszczególnych instrumentów tzw. czwartej rewolucji przemysłowej $\mathrm{w}$ polskich przedsiębiorstwach jest zróżnicowane $\mathrm{z}$ uwagi na posiadanie ograniczonych środków finansowych, umożliwiających realizację procesów produkcyjnych lub usługowych w odniesieniu do bieżących oczekiwań klientów (Kasprzak, 2005, s. 15; Flieger, 2016, s. 100-101). Integracja narzędzi Przemysłu 4.0 jest skoncentrowana na doskonaleniu dotychczasowych produktów, jak również zwiększeniu poziomu cyfryzacji podmiotów gospodarczych. Dlatego też decydenci przedsiębiorstw są skłonni do wprowadzenia zmian $\mathrm{w}$ dotychczasowym sposobie funkcjonowania. Wielokrotnie oznacza to konieczność utworzenia cyfrowych modeli biznesowych, uwzględniających zastosowanie szeroko pojętej informatyzacji procesów zarządzania. Decydenci funkcjonujący w obrębie $47 \%$ polskich przedsiębiorstw wskazują, iż czynnikiem decydującym o zastosowaniu tego rodzaju rozwiązań jest przede wszystkim dążenie do określenia bieżących predyspozycji klienta oraz późniejsza sprzedaż wyrobów poprzez wykorzystanie nowych kanałów dystrybucji i marketingu (Raport Przemyst 4.0 ..., 2017, s. 32). Oznacza to postępującą świadomość decydentów w odniesieniu do roli klienta $\mathrm{w}$ rozwoju organizacji. Ponadto funkcjonowanie polskich przedsiębiorstw wielokrotnie jest zależne od optymalizacji kosztów związanych $\mathrm{z}$ realizacją poszczególnych procesów produkcyjnych lub usługowych. Dlatego też filarem strategii biznesowych są inwestycje, mające na celu zakup i rozbudowę nowoczesnego zaplecza technologicznego. Niemniej jednak wysoce istotną rolę odrywa również doskonalenie zewnętrznych i wewnętrznych procesów logistycznych, serwisu i dystrybucji oraz marketingu (pionowy strumień wartości). Całokształt działań stanowi o produkcji wyrobów i ich sprzedaży klientom przy jednoczesnej eliminacji powstawania dodatkowych kosztów. Gwarancja serwisowania produktów w momencie wystąpienia nieprawidłowości funkcjonowania jest źródłem pozyskania zaufania klienta. W ramach pionowego strumienia wartości istotną rolę odgrywa również marketing, który wielokrotnie decyduje o nawiązaniu relacji kupna-sprzedaży.

Ocena wyników badań przedstawionych w raporcie przedsiębiorstwa PwC wskazuje, że rozwój współcześnie funkcjonujących przedsiębiorstw zależy od eliminacji czynników ograniczających procesy cyfryzacji poszczególnych struktur organizacyjnych. Znacząca liczba przedsiębiorstw wskazuje, że barierą zastosowania tego rodzaju 
rozwiązań i technologii jest konieczność inwestycji wysokich nakładów finansowych (46\%). Wielokrotnie działania te stanowią o wysokim poziomie ryzyka biznesowego, który jest źródłem niepokoju decydentów w odniesieniu do zwrotu poniesionych nakładów oraz utraty płynności finansowej. Z kolei pracownicy poszczególnych organizacji wskazują na niski poziom wsparcia ze strony kierownictwa w zakresie realizacji działalności innowacyjnej (33\%). Ocena wyników badań przedstawionych w raporcie wykazała, że pracownicy polskich przedsiębiorstw posiadają gruntowne wykształcenie i umiejętności, co wielokrotnie decyduje o uzyskaniu standardów, norm i certyfikacji, potwierdzających wysoką jakość produktów lub wykonania określonej usługi. Niemniej jednak $4 \%$ przedsiębiorstw wskazało, że nie posiada tego rodzaju dokumentacji.

Istniejąca konkurencyjność przedsiębiorstw skłania decydentów do koncentracji realizowanych procesów na określeniu oczekiwań klienta, którego świadomość nieustannie ewoluuje. Dostępność do wyrobów lub usług, znajdujących się $\mathrm{w}$ centrum jego zainteresowania, jest wysoka, dlatego też jest on skłonny ponieść dodatkowe koszty, jeśli będzie to oznaczało zakup produktu lub usługi wysokiej jakości z gwarancją obsługi na każdym etapie użytkowania. Współczesny konsument posiada wiedzę na temat poszczególnych przedsiębiorstw i wybiera świadomie produkt, który pozwoli na realizację wielokrotnie wygórowanych potrzeb. Działalność podmiotów gospodarczych oznacza zatem możliwość dostosowania oferty rynkowej do zmiennych upodobań klientów, co wielokrotnie jest możliwe w wyniku zastosowania narzędzi, usprawniających transfer danych i informacji z otoczenia, a w konsekwencji przemodelowanie systemów produkcyjnych w czasie rzeczywistym.

W ramach Przemysłu 4.0 producent ma dostęp do wiedzy zarówno o tworzonym przez siebie produkcie, jak i o rynku oraz jego potrzebach. Dzięki Internetowi Rzeczy (Internet of Things), Internetowi Wszechrzeczy (Internet of Everythings) oraz Internetowi usług (Internet of Services) wytwórca może wyposażyć swój produkt w sensory (czynniki) i mikoprocesory (Kiełtyka, Zygoń, 2018, s. 24-33). Ten tryb działania zapewni mu ciągłe zbieranie informacji we własnym know-how. Przy takim podejściu będzie wiedział już tak dużo, że na rynku będzie mógł sprzedawać de facto swoją wiedzę o produkcie, a nie sam sposób wytwarzania urządzenia. To w podejściu do działań MSP w Polsce kluczowa zmiana powodująca przejście od pracy bazującej na wykonywaniu instrukcji, czyli głównie montażu, gdzie rentowność jest niska do znajdowania kontrahentów. Dzięki takiemu podejściu mały przedsiębiorca zaczyna dysponować czymś, czego wcześniej nie posiadał.

\section{Stopień wykorzystania narzędzi Przemysłu $4.0 \mathrm{w}$ polskich przedsiębiorstwach}

D ostępność przedsiębiorstw do zasobów wiedzy w odniesieniu do korzyści zastosowania nowoczesnych narzędzi i technologii oraz sposobów zarządzania decy- duje o włączeniu działalności innowacyjnej do przyjętej strategii biznesowej. W tym celu podmioty gospodarcze decydują o inwestycji rocznie wypracowanych zysków w celu zwiększania poziomu ich innowacyjności (rys. 1).

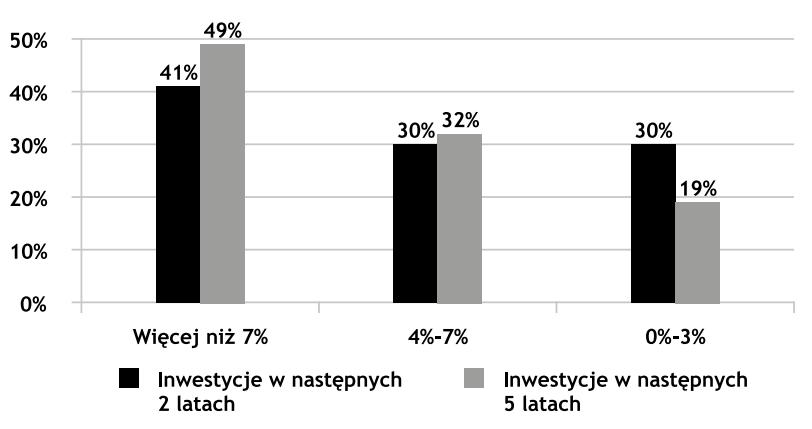

Rys. 1. Deklarowany odsetek wypracowanych przychodów, który przedsiębiorstwa są skłonne przeznaczyć w celu zwiększania poziomu cyfryzacji

Źródło: opracowanie własne na podstawie: Raport Przemyst $4.0 \ldots, 2017$, s. 33

W pespektywie następnych 2 lat $41 \%$ polskich przedsiębiorstw zamierza przeznaczyć więcej niż 7\% wypracowanych rocznie przychodów w celu zwiększenia poziomu ich cyfryzacji. Z kolei w okresie najbliższych 5 lat odsetek podmiotów gospodarczych, deklarujących zwiększanie poziomu innowacyjności, ma zwiększyć się do poziomu $49 \%$. Organizacje funkcjonujące na rynku polskim deklarują również dążenie do zakupu nowoczesnych rozwiązań i technologii, natomiast prognozowana roczna ilość przeznaczonych środków na realizację inwestycji ma być niższa:

- inwestycje w najbliższych 2 latach - 30\% respondentów zadeklarowało finansowanie w granicach 4\%-7\% i 0\% - 3\% wypracowanych zysków,

- inwestycje w najbliższych 5 latach - 32\% respondentów zadeklarowało finansowanie w granicach $4 \%-7 \%$ oraz $19 \%$ zadeklarowało finansowanie w przedziale $0 \%-3 \%$ wypracowanych zysków.

Wykorzystanie nowoczesnych rozwiązań i technologii stanowi o postępującej świadomości decydentów w zakresie przyszłych korzyści osiąganych przez przedsiębiorstwo, między innymi w wyniku pozyskania większej liczby klientów (rys. 2).

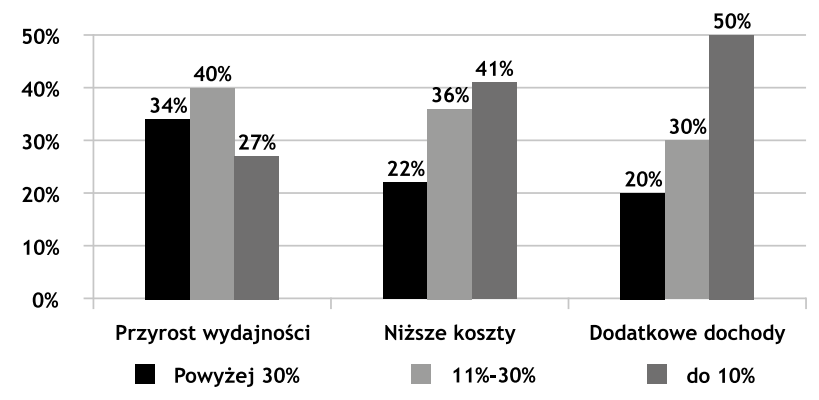

Rys. 2. Korzyści implementacji rozwiązań cyfrowych w perspektywie najbliższych 5 lat w polskich przedsiębiorstwach

Źródto: opracowanie własne na podstawie: Raport Przemyst $4.0 \ldots, 2017$, s. 34 
Prognozowany wzrost wydajności w okresie najbliższych 5 lat będzie oscylował w graniach $11 \%$-30\%, co stanowi $40 \%$ polskich przedsiębiorstw, które wzięły udział w badaniu PwC. W przypadku przypuszczalnego obniżenia kosztów $41 \%$ podmiotów gospodarczych zadeklarowało ich obniżenie do $10 \%$. Z kolei ocena dotycząca pozyskania dodatkowych przychodów wykazała, że w $50 \%$ organizacji powinny one wzrosnąć do poziomu 10\%. Prognozy w odniesieniu do korzyści implementacji rozwiązań cyfrowych wskazują na realizację nadrzędnych celów przez decydentów polskich przedsiębiorstw. Prawdopodobnie $\mathrm{w}$ tej grupie respondentów znajdują się jednostki, będące w fazie wdrożeniowej tego rodzaju narzędzi, a osiąganie przez nie zwrotu poniesionych nakładów stanowi o kontynuacji trendów w tym zakresie.

\section{Koncepcyjny model zarządzania procesowego, bazujący na wysoko zaawansowanych narzędziach informatyzacji, analityki i robotyzacji procesów produkcyjnych}

D ermanentnie skracający się cykl życia produktu jest wynikiem rozwoju społeczno-gospodarczego i postępującej świadomości konsumentów. Wybór odpowiednich instrumentów zarządzania przedsiębiorstwem pozwala na dostosowanie się do zmian otoczenia zewnętrznego z uwzględnieniem możliwości w odniesieniu do firm konkurencyjnych. Pośród narzędzi wykorzystywanych w ramach Przemysłu 4.0 należy wskazać urządzenia funkcjonujące $\mathrm{w}$ oparciu o robotyzację i automatyzację produkcji, oprogramowanie prototypowania i wprowadzanie na rynek nowych produktów oraz wysoko zaawansowane narzędzia analityczne (Raport Smart Industry Polska, 2018, s. 35).

Narzędzia, które zostały zaproponowane w koncepcji modelu zarządzania procesowego, obejmują nowe technologie Przemysłu 4.0, wspomagając cyfryzację i informatyzację licznych procesów produkcyjnych. Do grupy narzędzi istotnych do skutecznego działania zaproponowanego w artykule modelu należą:

- Systemy cyfrowo-fizyczne (Cyber-Physical-Systems),

- Internet Rzeczy (Internet of Things),

- Internet Wszechrzeczy (Internet of Everythings),

- Internet Usług (Internet of Service),

- Techniki analizy dużych zbiorów danych (Big Data),

- Chmura obliczeniowa (Cloud Computing),

- Cyfrowy bliźniak (Digital Twin) ${ }^{\mathbf{6}}$,

- Systemy cyberbezpieczeństwa (Cybersecurity Systems),

- Technologie w postaci druku addytywnego, przestrzennego (3D),

- Zaawansowane symulacje (Advanced Simulations),

- Rzeczywistość wirtualna (Virtual Reality) i rozszerzona (Augmented Reality),

- Pełna integracja systemów informatycznych w przedsiębiorstwie i w jego obrębie na różnych etapach (Integration of IT Systems),

- Sztuczna inteligencja (Artificial Intelligence) umożliwiająca, np. działanie pojazdów autonomicznych,

- Przemysłowy Internet Rzeczy (Industrial Internet of Things),
- Systemy bazujące na etykietach, tzw. tagach w technologii RFID (Radio Frequency Identification),

- Systemy typu MES (Manufacturing Execution System),

- Standard OPC komunikacyjny używany w automatyce przemysłowej (Open Communication Standard).

Czwarta rewolucja przemysłowa przyspieszyła wdrażanie nowoczesnych rozwiązań w obszarze konkurencyjności produkcji i nadała dodatkowej dynamiki procesowi stałego dostosowywania się przedsiębiorstw do zmian technologicznych.

Innowacyjność w zakresie wykorzystania technologii informatycznych i komunikacyjnych (ICT - Information and Communications Technologies) jest wynikiem zmian $\mathrm{w}$ dostępnych sposobach komunikacji i transferu informacji. Ponadto ich wykorzystanie znacząco usprawnia przepływ produktów i kapitału, ale również dostępność do zgromadzonych zasobów wiedzy użytecznej. Wykorzystanie nowoczesnych technologii w połączeniu $\mathrm{z}$ dostępną wiedzą, umiejętnościami i doświadczeniem pracowników pozwala również na generowanie nowych źródeł wiedzy, między innymi w zakresie możliwości i predyspozycji przedsiębiorstwa w odniesieniu do nowych kierunków działalności, czy opracowania modeli biznesowych, uwzględniających całościowe zarządzanie organizacją (Kiełtyka, 2017b, s. 33-34).

W aspekcie procesowego zarządzania przedsiębiorstwem proces implementacji wysoko zaawansowanych narzędzi informatyzacji, analityki i robotyzacji procesów produkcyjnych można usprawnić poprzez zaproponowany przez autorów koncepcyjny model zarządzania procesowego. Przedstawia on przebieg następujących po sobie etapów realizacji określonych przedsięwzięć inwestycyjnych w wyniku zastosowania wybranych technologii ICT (rys. 3).

Kluczowym elementem realizacji przedsięwzięć inwestycyjnych jest pozyskanie i późniejsza analiza danych i informacji w odniesieniu do bieżącej sytuacji przedsiębiorstwa, działalności firm konkurencyjnych oraz predyspozycji w aspekcie możliwości dostosowania się do uwarunkowań rynkowych. Ponadto kluczowym elementem procesu analizy otoczenia organizacji jest dążenie do określenia preferencji i oczekiwań klientów w wyniku wielopoziomowych interakcji klienta i profilowania klientów (procesy wejścia realizowanych przedsięwzięć inwestycyjnych). Pozyskanie danych wejściowych i informacji na tym etapie za pomocą zaawansowanych algorytmów pozwala na ich przesyłanie w czasie rzeczywistym $\mathrm{z}$ wykorzystaniem wyżej wymienionych narzędzi, a tym samym przetwarzanie w wiedzę użyteczną. Danymi wejściowymi są również informacje gospodarcze uzyskiwane poprzez: Internet, prasę, radio i telewizję oraz publikowane dane statystyczne. Informacje gromadzone są w bazach i hurtowniach danych, zlokalizowanych w narzędziach chmury obliczeniowej na bazie wirtualnych dysków, jak również Internecie Rzeczy czy Internecie Wszechrzeczy (procesy przetwarzania zgromadzonych danych i informacji). Z kolei systemy cyfrowo-fizyczne (CPS - Cyber-Physical System) pozwalają na budowanie inteligentnych sieci, a tym samym integrację poszczególnych struktur organizacyjnych oraz współpracę i wymianę informacji przez 


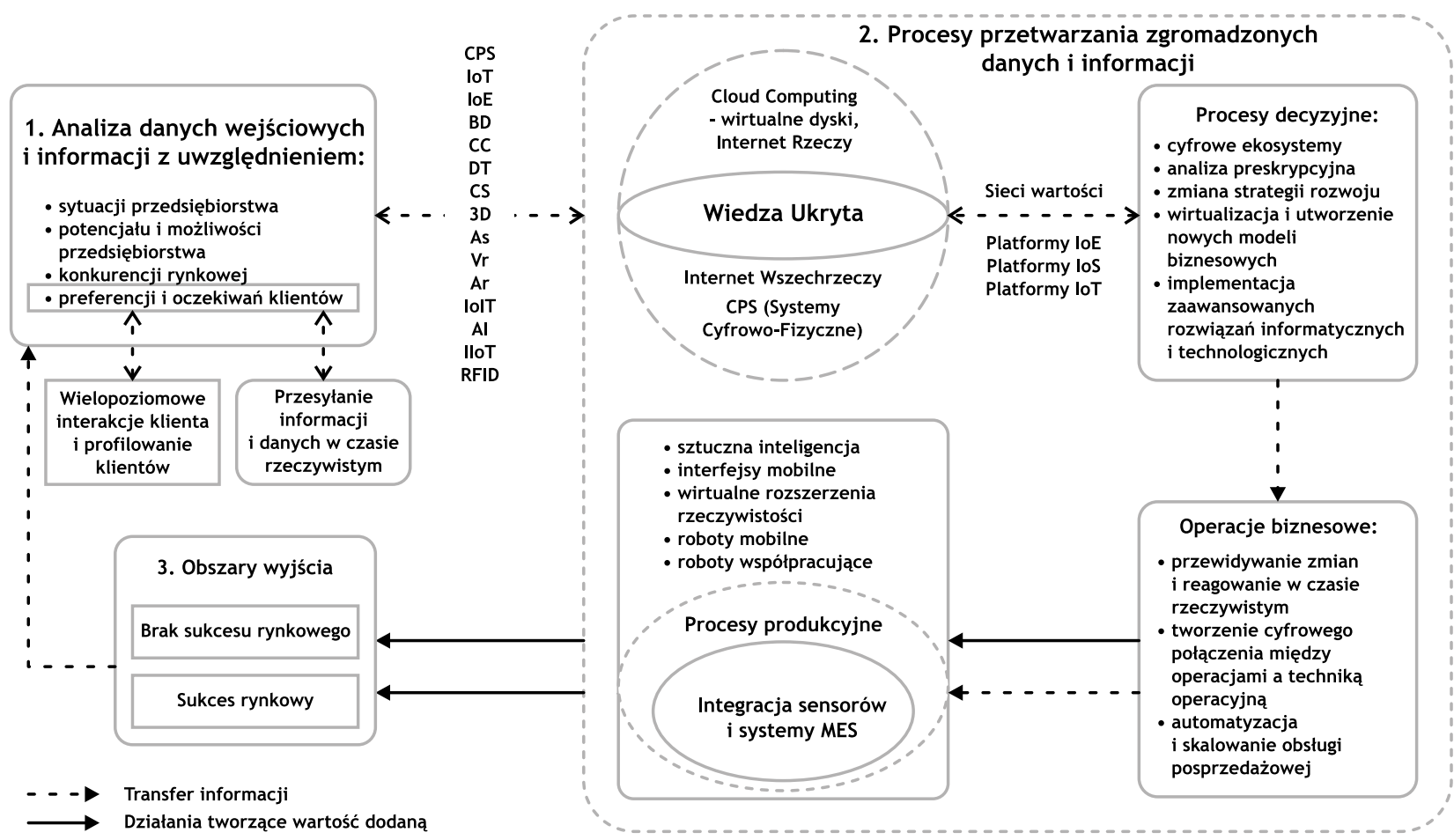

Rys. 3. Koncepcyjny model zarządzania procesowego, bazujący na wysoko zaawansowanych narzędziach informatyzacji, analityki i robotyzacji procesów produkcyjnych, gdzie: CPS (Cyber-Physical-Systems), loT (Internet of Things), loE (Internet of Everythings), loS (Internet of Service), BD (Big Data), CC (Cloud Computing), DT (Digital Twin), CS (Cybersecurity Systems), 3D (3D printing), As (Advanced Simulations), $\operatorname{Vr}$ (Virtual Reality), Ar (Augmented Reality), IolT( Integration of IT Systems), Al (Artificial Intelligence), IloT (Industrial Internet of Things), RFID (Radio Frequency Identyfications), MES (Manufacturing Execution Systems)

Źródło: opracowanie własne

poszczególnych pracowników. Dostęp do zgromadzonych zasobów wiedzy mają wszyscy pracownicy, posiadający konto na platformach Internet of Things czy Internet of Everythings, co pozwala na skrócenie czasu realizacji procesów decyzyjnych przez kierownictwo organizacji.

Rozwój przedsiębiorstw funkcjonujących w warunkach postępującego zjawiska konkurencji rynkowej jest uzależniony od wprowadzenia zmian w dotychczasowym sposobie zarządzania. Zmiany te są skoncentrowane na utworzeniu nowych modeli biznesowych, jak również wykorzystaniu cyfrowych ekosystemów, a tym samym realizacji nadrzędnych celów strategicznych. Ponadto kluczową rolę w zwiększaniu przewagi konkurencyjnej na rynku odgrywają implementacja zaawansowanych rozwiązań informatycznych i technologicznych oraz analiza preskrypcyjna. Działania te decydują o usprawnieniu przebiegu realizowanych procesów, a tym samym produkcji wyrobów wysokiej jakości. Niemniej jednak nawiązanie długotrwałych relacji z klientem zależy od przebiegu procesów decyzyjnych i operacji biznesowych, uwzględniających obsługę klientów na każdym etapie cyklu życia produktu (Ślusarczyk, 2019, s. 8). Operacje biznesowe to całokształt działań organizacji, podejmowanych $\mathrm{w}$ celu określenia zmian zachodzących $\mathrm{w}$ otoczeniu zewnętrznym (działalność konkurencji, zmiany preferencji klientów) oraz możliwość dostosowania się do nich w czasie rzeczywistym z uwzględnieniem bieżących zapotrzebowań popytowych. Takie podejście w zarządzaniu relacjami z klientem pozwala na pełną obsługę posprzedażową, między innymi poprzez skalowanie dóbr lub usług. W momencie wystąpienia nieprawidłowości w funkcjonowaniu zakupionych towarów istnieje zwiększone prawdopodobieństwo ich eliminacji, a tym samym pozyskanie zadowolenia i zaufania konsumenta. Całokształt działań stanowi wypadkową gwarancji serwisowania wyrobów i możliwość oszczędności środków finansowych lub zwrotu poniesionych nakładów przez klienta.

Przemysł 4.0 narzuca również zmiany w sposobach wprowadzania do obrotu nowych produktów i usług. Zastosowanie nowoczesnych rozwiązań informatycznych, komunikacyjnych, technologicznych i zarządczych pozwala na wielopłaszczyznową wymianę informacji. W ten sposób następuje dostosowanie się do potrzeb klientów i produkcji odpowiadającej obecnym zapotrzebowaniom popytowym (Just-in-Time), co z kolei stanowi źródło oszczędności środków finansowych (Kiełtyka, 2017b, s. 33-34). Wykorzystanie zintegrowanych systemów planowania i harmonogramowania produkcji oraz systemów planowania i zarządzania zasobami (informacje na temat stanów magazynowych i wielkości zamówień) w ramach integracji pionowej i systemów MES ${ }^{7}$ (Manufacturing Execution Systems) pozwala na realizację działań zwiększających efektywność i wydajność procesów, między innymi w wyniku (Francik, Pudło, 2016, s. 179-189):

- zarządzania produkcją,

- zarządzania efektywnością,

- prowadzenia obserwacji i genezy produkcji, 
- realizacji procesów zarządzania jakością,

- gromadzenia i przetwarzania danych produkcyjnych,

- zarządzania przepływem dokumentów,

- zarządzania alokacją zasobów,

- zarządzania zasobami ludzkimi,

- alokacji zadań produkcyjnych,

- harmonogramowania produkcji.

Z kolei digitalizacja i automatyzacja procesów pozwala na optymalne i racjonalne wykorzystanie zasobów intelektualnych, a także realizację działań operacyjnych, będących składowymi cyklu produkcyjnego. Wykorzystanie transferu danych $\mathrm{w}$ czasie rzeczywistym pozwala na bieżącą ocenę funkcjonowania i sprawności wykorzystywanych $\mathrm{w}$ produkcji urządzeń oraz optymalizację czasu napraw celem ograniczenia przestojów i powstania zbędnych kosztów (algorytmy wykorzystywane do optymalizacji napraw i czasu pracy poszczególnych urządzeń produkcyjnych). Oznacza to optymalizację ryzyka biznesowego do poziomów, pozwalających na realizację uprzednio przyjętych założeń, a tym samym odniesienie sukcesu rynkowego. W przypadku wystąpienia sytuacji zakłócających proces produkcyjny zadania realizowane $\mathrm{w}$ ramach określonego przedsięwzięcia inwestycyjnego należy powtórzyć. Ma to na celu powtórną weryfikację i ocenę słuszności podjętych działań, a w przypadku wystąpienia błędów i nieprawidłowości ich eliminację (procesy wyjścia w postaci utworzonej wartości dodanej realizowanych przedsięwzięć inwestycyjnych).

\section{Podsumowanie}

R ozwój przedsiębiorstw w warunkach postępującej globalizacji rynkowej zależy od ich zdolności do zastosowania rozwiązań innowacyjnych. Zakres prowadzonych przedsięwzięć inwestycyjnych obejmuje zastosowanie nowoczesnych urządzeń i technologii produkcyjnych, ale przede wszystkim zastosowanie nowych sposobów zarządzania, pozyskiwania danych i informacji oraz ich przekształcenie w zasoby wiedzy użytecznej.

Pośród przedsiębiorstw funkcjonujących na rynku polskim, jak również na rynkach światowych można zaobserwować postępującą tendencję w zakresie wykorzystania wszelkiego rodzaju rozwiązań umożliwiających zwiększenie wydajności realizowanych procesów oraz wypracowania przychodów, a tym samym obniżenia kosztów produkcji. W perspektywie dalszego rozwoju decydenci przedsiębiorstw są skłonni do przeznaczenia blisko $7 \%$ rocznych zysków na finansowanie działalności innowacyjnej. Oznacza to świadomość podmiotów gospodarczych do przystosowania się w taki sposób, aby czerpać korzyści wynikające z zaspokojenia oczekiwań i preferencji konsumentów.

Koncepcyjny model zarządzania procesowego przedstawia istotniejsze zależności pomiędzy stosowanymi aktualnie coraz powszechniej procesami komunikacyjnymi, między którymi identyfikuje się wzajemne powiązania i relacje. Współdziałanie stosowanych procesów komunikacyjnych daje także związki i zależności, które warunkują jednoczesne tworzenie wartości dla klientów i przedsiębiorstwa (Nowosielski, 2009, s. 424).
Determinantą rozwoju przedsiębiorstw jest również opracowanie strategii rozwoju, funkcjonującej w oparciu o podejście procesowe zarządzania. W zarządzaniu procesowym należy utworzyć systemy zarządzania talentami i wykorzystywać strategię zarządzania zasobami ludzkimi, które wpisują się $\mathrm{w}$ ramy strategii korporacyjnej, zapewniając jednocześnie niezbędne środki wykorzystywane $\mathrm{w}$ procesach zmian (Wyrwicka, Mrugalska, 2017, s. 385). W tym celu podmioty gospodarcze powinny dążyć do utworzenia nowych modeli biznesowych, które pozwolą na sprecyzowanie parametrów procesów, określenia ich elementów składowych z uwzględnieniem zastosowania rozwiązań usprawniających ich realizację. Pozwoli to na zmniejszenie ryzyka niepowodzenia, a tym samym zwrot poniesionych nakładów.

Obszar znaczeniowy Przemysłu 4.0 wykracza poza samo wytwarzanie produktu. Obserwując dotychczasowe działania przedsiębiorstw, można stwierdzić, że procesy fizycznej realizacji produktu w większości odbywają się w rozproszonych lokalizacjach. Stosując się do wymogów stawianych przez Przemysł 4.0, następuje koncentracja danych zarówno $\mathrm{z}$ procesu wytwórczego, jak i z całego cyklu życia produktu. $Z$ pełną świadomością można przyjąć, że pozyskiwana informacja umożliwia dostosowywanie $\mathrm{w}$ czasie rzeczywistym realizacji we wszystkich składowych łańcucha wartości do aktualnych potrzeb wszystkich resortów przemysłowych. Chcąc nadążyć za szybkimi i przemysłowymi zmianami, które bazują na produkcji cyfrowej, komunikacji sieciowej, obszarach technologii komputerowych i automatyzacji, pracownicy powinni radykalnie zmienić struktury organizacyjne.

\section{prof. dr hab. inż. Leszek Kiełtyka \\ Politechnika Częstochowska \\ Wydział Zarządzania \\ ORCID: 0000-0001-7551-491X \\ e-mail: leszek.kieltyka@wz.pcz.pl}

\section{mgr inż. Kamila Charciarek \\ Politechnika Częstochowska \\ Wydział Zarządzania \\ ORCID: 0000-0002-2656-239X \\ e-mail: kamilaa.francik@gmail.com}

\section{Przypisy}

1) Ryzyko utraty reputacji - stanowi ocenę działalności przedsiębiorstw przez określoną grupę interesariuszy z uwzględnieniem ich bieżących potrzeb i oczekiwań. Ryzyko utraty reputacji stanowi różnicę pomiędzy stopniem oczekiwań poszczególnych grup klientów a możliwością ich realizacji przez podmioty gospodarcze. Jego poziom zależy od rozpowszechniania prawdziwych lub nieprawdziwych informacji przez klientów lub firmy konkurencyjne oraz realizację działań, które w znaczącym stopniu mogą stanowić o funkcjonowaniu jednostki. Konsekwencją działań jest utrata zaufania interesariuszy, a tym samym zmniejszenie wypracowanych zysków przedsiębiorstw. 
2) Czwarta rewolucja przemysłowa (ang. Fourth Industrial Revolution; Przemysł 4.0 - ang. Indystry 4.0, niem. Industrie 4.0) - oznacza powszechną i postępującą cyfryzację przedsiębiorstw oraz integrację poszczególnych struktur organizacyjnych i zatrudnionych pracowników z urządzeniami wykorzystywanymi w procesach produkcyjnych. W ramach czwartej rewolucji przemysłowej można zaobserwować dążenie podmiotów gospodarczych do zwiększania poziomu ich innowacyjności, między innymi w wyniku implementacji: systemów cyfrowo-fizycznych czy technologii cyfrowych, takich jak: Internet Rzeczy, Big Data, Cloud Computing, usieciowienie, decydujących o sukcesywnym i całościowym zarządzaniu organizacją.

3) Procesowe podejście w zarządzaniu przedsiębiorstwem - założenie, które pozwala określić przedsiębiorstwo jako zintegrowany system, realizujący poszczególne procesy w momencie zakończenia ciągu następujących po sobie czynności i operacji. Podejście to wymaga od decydentów jednostki określenia i przyjęcia odpowiednich parametrów czasowych, finansowych i technicznych. Działania te umożliwiają integrację czasu, jakości, a także terminowości wykonywanych działań, których celem jest dostarczenie klientowi wyrobów lub usług najwyższej jakości, dostosowanych do ich indywidualnych preferencji. W konsekwencji dochodzi do zwiększenia prawdopodobieństwa realizacji celów określonych w długofalowej strategii rozwoju oraz zwrotu poniesionych nakładów inwestycyjnych. W podejściu procesowym do zarządzania istotnym elementem jest utworzenie unikalnych modeli biznesowych, które pozwalają na pełne wykorzystanie potencjału przedsiębiorstwa oraz eliminację występujących nieprawidłowości, a tym samym zwiększenie jakości oferowanych produktów, między innymi w wyniku realizacji procesów kontroli i nadzoru. Podobnego stwierdzenia użyła A. Bitkowska (2017, s. 124), która uważa, że zarządzanie procesowe wpływa w znacznym stopniu na zarządzanie przedsiębiorstwem.

4) PricewaterhouseCoopers ( $\mathrm{PwC})$ - międzynarodowa sieć przedsiębiorstw, prowadzących działalność w zakresie świadczenia usług audytorskich, księgowych i doradczych. Jednostka została utworzona w 1998 r. w wyniku integracji Price Waterhouse oraz Coopers\&Lybrand.

5) Raport Przemysł 4.0, czyli wyzwania współczesnej produkcji powstał w oparciu o badanie, które zostało przeprowadzone w 26 krajach, pośród 2000 osób zatrudnionych w różnych sektorach gospodarki. W grupie respondentów pięćdziesięciu wskazało, iż są zatrudnieni w polskich przedsiębiorstwach. Celem badania była ocena szans, wyzwań i zagrożeń czwartej rewolucji przemysłowej i jej wpływu na rozwój organizacji.

6) Cyfrowy bliźniak (Digital Twin) - jest to narzędzie wspierane przez wysoko zaawansowane rozwiązania analityczne z obszaru tzw. Smart Factory. Wykorzystanie cyfrowego bliźniaka w działalności przedsiębiorstw pozwala na przedstawienie operacji i procesów w postaci cyfrowych symulacji, co w znaczącym stopniu może przyczynić się do skrócenia czasu projektowania produktów oraz realizacji procesów produkcyjnych. Ponadto ciągła dostępność do sieci Internet pozwala na wprowadzenie zmian cyklu produkcyjnego w czasie rzeczywistym, a tym samym pełną koncentrację na potrzebach klientów na każdym etapie użytkowania wyrobu lub usługi $\mathrm{z}$ uwzględnieniem procesów prototypowania i testowania.

7) Systemy Realizacji Produkcji (Manufacturing Execution System-MES).

\section{Bibliografia}

[1] Bembenek R. (2017), Klastry przemystu 4.0 w zrównoważonej gospodarce opartej na wiedzy, Prace Naukowe Uniwersytetu Ekonomicznego we Wrocławiu, Nr 491, s. 31-44.

[2] Bitkowska A. (2017), Zarządzanie wiedza w organizacjach procesowych, [w:] L. Kiełtyka, P. Kobis (red.), Wybrane zagadnienia zarządzania współczesnymi przedsiębiorstwami, Wydawnictwo Politechniki Częstochowskiej, Częstochowa, s. 123-133.

[3] Flieger M. (2016), Process Management in the Local Offices. Model of Adaptation of the Process Maturity Criteria, Wyd. UAM, Poznań.

[4] Francik K., Pudło M. (2016), Znaczenie systemów realizacji produkcji jako element zarządzania ryzykiem, [w:] L. Kiełtyka, W. Jędrzejczyk, P. Kobis (red.), Wyzwania współczesnego zarządzania. Kreowanie kapitału intelektualnego organizacji, Towarzystwo Naukowe Organizacji i Kierownictwa, Warszawa, s. 179-189.

[5] Kasprzak T. (2005), Modele referencyjne $w$ zarządzaniu procesami biznesu, Wyd. Difin, Warszawa.

[6] Kiełtyka L. (2017a), Inspiracje i innowacyjność w zarzqdzaniu współczesnymi organizacjami. Wykorzystanie nowoczesnych technologii $w$ tworzeniu innowacyjnych strategii organizacji, „Przegląd Organizacji”, Nr 7, s. 32-37.

[7] Kiełtyka L. (2017b), Narzędzia i technologie multimedialne wspomagajace pracę menedżera we współczesnych organizacjach, „Przegląd Organizacji”, Nr 8, s. 33-42.

[8] Kiełtyka L., Zygoń O. (2018), Wspótczesne formy komunikacji - jak zarządzać z wykorzystaniem Internetu Rzeczy i Wszechrzeczy, „Przegląd Organizacji”, Nr 2, s. 24-33.

[9] Kraszewska M., Pujer K. (2017), Konkurencyjność przedsiębiorstw. Sposoby budowania przewagi konkurencyjnej, Wydawnictwo Exante, Wrocław.

[10] Nowosielski S. (2009), Podejście procesowe w organizacjach, Prace Naukowe Uniwersytetu Ekonomicznego we Wrocławiu, Nr 52, s. 183-198.

[11] Olender-Skorek M. (2017), Czwarta rewolucja przemysłowa a wybrane aspekty teorii ekonomii, „Nierówności Społeczne a Wzrost Gospodarczy”, Nr 51, s. 38-49.

[12] Raport Przemysł 4.0, czyli wyzwania współczesnej produkcji, PwC, listopad 2017.

[13] Raport Smart Industry Polska 2018. Innowacyjność w sektorze mikro oraz małych $i$ średnich przedsiębiorstw produkcyjnych $w$ Polsce, Warszawa, kwiecień 2018.

[14] Silvestro R. (1998), The Manufacturing TQM and Service Quality Literatures: Synergistic or Conflicing Pardigins? „International Journal of Quality\&Reliability Management”, No. 3, pp. 303-328.

[15] Sobińska M. (2016), Rola IT we wspótczesnych modelach biznesu, „Informatyka Ekonomiczna”, Nr 3(41), s. 92-105.

[16] Szwajca D., Media społecznościowe jako źródło ryzyka reputacyjnego przedsiębiorstwa (2017), Studia Ekonomiczne. Zeszyty Naukowe Uniwersytetu Ekonomicznego w Katowicach, Nr 322, s. 230-242.

[17] Szwajca D., Rydzewska A., Nawrocki T. (2014), Identyfikacja kosztów pogorszenia reputacji przedsiębiorstwa z perspektywy interesariuszy, „Przegląd Organizacji”, Nr 4, s. 10-15. 
[18] Ślusarczyk B. (2019), Potencjalne rezultaty wprowadzenia koncepcji Przemystu $4.0 \mathrm{w}$ polskich przedsiębiorstwach, „Przegląd Organizacji”, Nr 1, s. 4-10.

[19] Wyrwicka M.K., Mrugalska B. (2017), Industry 4.0 - Towards Opportunities and Challenges of Implementation, 24th International Conference on Production Research, pp. 382-387.

[20] Zaskórski P., Warszewski P. (2015), Model zarządzania procesowego $w$ doskonaleniu systemów logistycznych, „Gospodarka Materiałowa i Logistyka”, Nr 5, s. 809-825.

\section{Model Process Management with the Use of Modern Tools of Industry 4.0}

\section{Summary}

Progressive consumer awareness, resulting from their desire to purchase high-quality products or services, encourages decision-makers of enterprises to introduce changes in the management of the organisation. Due to the volatility of market conditions and trends and the increasing competitiveness of business entities, these changes require an increase in the scope of investment projects carried out, among others through the use of highly advanced tools of Industry 4.0. Their use in individual areas of enterprises can significantly improve the functioning of the organisation by increasing the resources of useful knowledge. All of the activities will allow for adjusting the market offer to the existing needs and expectations of customers, and thus fully use the potential of the organisation. The aim of the study is to assess the activity of Polish enterprises, taking into account the aspirations of individual business entities to purchase and implement Industry 4.0 tools. An element of the study is also a conceptual model of process management, based on highly advanced IT tools, broadly understood analytics and robotisation of production processes. According to the authors, the application of the developed model can significantly improve the functioning of enterprises, among others as a result of increased knowledge transfer, and thus shortening the time of implementation of individual production processes, sales and distribution of products in relation to existing demand.

\section{Keywords}

innovativeness of enterprises, Industry 4.0, management process computerization, process management 